Gender Ideology, Division of

Housework, and the Geographic

Mobility Families

Hendrik Jürges

90-2005

May2005 


\title{
Gender Ideology, Division of Housework, and the Geographic Mobility Families
}

\author{
Hendrik Jürges \\ Mannheim Research Institute for the Economics of Aging \\ University of Mannheim \\ L13, 17 \\ D-68131 Mannheim \\ Germany \\ Tel: +49-621-181-3519 \\ Fax: +49-621-181-1863 \\ Email: juerges@mea.uni-mannheim.de
}

This version: May 2005

\footnotetext{
* Part of this research was conducted while I was a guest researcher at the Deutsches Institut für Wirtschaftsforschung (DIW), whose hospitality is gratefully acknowledged. I would like to thank Miriam Beblo, Axel Börsch-Supan, Karsten Hank, and Konrad Menzel for helpful comments.
} 


\begin{abstract}
The paper studies the relevance of gender ideology for the geographic mobility of families using data from the German Socio-economic Panel. The analysis proceeds in two steps. First, it is shown single men and women - who are in some sense "unconstrained" optimizers - reveal identical mobility patterns. There are no fundamental gender differences in the inter-regional mobility of German singles. Second, I focus on dual-earner households and split this group into "traditional" and "egalitarian" couples using information on their factual division of housework rather than their reported gender ideology. Separate migration analyses for both groups reveal important differences indicating the significance of gender ideology in families' migration behavior: job-related characteristics of men statistically dominate those of women in traditional couples, whereas in egalitarian couples, male and female characteristics have the same effect on family migration behavior, i.e. there is no gender bias. Failure to account for the heterogeneity in gendered family roles across families thus misses an important explanatory factor in migration research.
\end{abstract}

Keywords: Division of household labor, dual-earner couples, gender ideology, migration 


\section{Gender Ideology, Division of Housework, and the Geographic Mobility Families}

\section{INTRODUCTION}

The aim of this article is to study the determinants of family migration decisions, i.e. the decision to make long-distance moves (within countries but across regional borders). Specifically, I will assess the significance of gender ideology or gender-role beliefs for the inter-regional mobility of dual-earner households. Traditional gender-role beliefs imply that the husband should have the role of the primary provider or breadwinner. His labor market career concerns are of vital interest for the entire family. The wife, if at all employed, merely assumes the role of a co-provider. Her career is of minor importance, more or less expendable. In contrast, egalitarian gender-role beliefs ascribe the same importance to both partner's careers, at least in principle. The potential importance of gender-role beliefs for family decisions such as where to locate is obvious. If only one partner's job and career are deemed important for the well-being of the entire family, families will be less restrained in their decisions by losses of the partner who is the secondary provider.

Economic and sociological family migration models differ in their assessment of the importance of gender ideology: sociologists think that gendered family roles play a major role in family migration decisions (Bielby and Bielby, 1992; Bird and Bird, 1985), whereas economists usually ignore this kind of concept (DaVanzo, 1976; Mincer, 1978). However, empirically, the differences between economic and sociological models are subtle. Mainly because married women usually have less favorable positions in the labor market than men, the main predictions are very similar: Dual-earner couples are less mobile than single-earner couples, because the wife's employment has some effect on migration propensities, but men's careers are more important in the migration decision. Hence women tend to lose (in terms of 
their labor market position) in case of a family move. Economists assert that this is the case only because men's potential gains from migration outweigh women's potential losses (Mincer, 1978; Nivalainen, 2004). In contrast, sociologists argue that the relative importance of husband's and wife's job is not only a function of their income or labor market position in general, but also of the gender ideology shared in the couple (Bielby and Bielby, 1992; Bird and Bird, 1985; Morrison and Lichter, 1988; Shihadeh, 1991).

The basic individual-level migration model endorsed by most sociologists and economists was developed by Sjaastad (1960). According to this model, potential migrants evaluate discounted costs and benefits of migrating to another region. If benefits outweigh costs (if the net benefit is larger than zero), the individual moves to the other region. Benefits are usually job related. Individuals move from low-wage regions to high-wage regions, or from regions with high unemployment rates to regions with low unemployment rates. The costs of moving are mostly in terms of leaving behind location specific capital in various forms - family, friends, memories, an so on. Sjaastad calls this the "psychic costs" of migration. Gains and benefits are thus not entirely in monetary terms.

Although the Sjaastad model is useful in describing the migration behavior of men, it has limited value for the explanation of the regional mobility of married women. (Bielby and Bielby, 1992; Mincer, 1978; Morrison and Lichter 1988; Sandell, 1977, Shihadeh, 1991). The general finding is that family migration decisions are largely dominated by husbands, even if wives are employed. Individual (job-related) returns to migration differ substantially between men and women. Married men who migrate are less often unemployed after a move and they enjoy increased wages. In contrast, women are migration losers in the sense that they are less often employed, have given up a qualified occupation, or earn less after a move (Boyle, Cooke, Halfacree and Smith, 2001; Büchel, 2000; Duncan and Perrucci, 1976; Jürges, 1998b; Lichter, 1983; Maxwell, 1988; Morrison and Lichter; 1988; Spitze, 1984). 
Mincer (1978) extended the Sjaastad model to families. According to his model, a family moves if and only if the sum of all household members' benefits from moving is larger than the sum of all household members' losses. In this case, each household member benefits from the move, either directly (e.g., in the form of higher wages) or because he or she receives compensation from other family members that undo migration losses. The Mincer model allows to distinguish four different situations in which family migration decisions take place. For sake of exposition, let us consider a two-member household with a husband and a wife:

- The net benefit of moving to another region is greater or equal to zero for each partner. In this case the family will move.

- Only one partner gains from the move and the benefits accruing to this partner are larger than the loss of the other partner. Because the sum of individual gains and losses is larger than zero, family utility is maximized by moving and hence the family will move. The partner who moves although he or she is losing individually is called "tied mover." In order to agree to the move, the "tied mover" must be compensated for this loss.

- Only one partner gains from the move and the benefits accruing to this partner are smaller than the loss of the other partner. Then the sum of individual gains and losses is smaller than zero and the family will not move. The partner who remains at his or her present location although he or she would benefit individually is called the "tied stayer." It is not clear if and how this partner is compensated.

- The household splits up if the sum of individual utilities is larger when both partners go separate ways rather than staying together at the same location. Although Mincer speaks of divorce, this needs of course not necessarily be the case. Dual-career couples also commute long distances, for instance on a weekly or monthly basis, to accommodate partnership and careers. 
Although being rather simplistic, the Mincer model makes several empirical predictions that are well confirmed (DaVanzo, 1981; Lichter, 1982; Long, 1974; Nivalainen, 2004):

- Single person households have a higher geographical mobility than couples or larger families.

- Dual-earner couples are less likely to move than single-earner couples, because the tied mover will suffer from disruptions of his or her professional career.

- Because of an inferior labor market position, women are more often the "tied" partner (mover or stayer) than men. Families move to accommodate the husband's professional careers rather than the wife's.

Mincer's model of family migration has been criticized as being incomplete by economists and sociologists alike. The economists' critique mainly deals with the model's missing specification of the distribution of the resources in the household. For instance, that migration losers are compensated is simply assumed but not founded theoretically. This is no longer deemed acceptable in modern economic household theory. Households form because there are gains from marriage that leave each partner better off than when living alone. The distribution of these gains between husband and wife is now explicitly modeled as the outcome of a bargaining process (specifically as a Nash-bargaining solution; see Manser and Brown, 1980; McElroy and Horney, 1981). Nash-bargaining is a formalization of the famous "law of personal exploitation" (Ross, 1921): the partner who has less to lose from a divorce will be able to extract more of the benefits of marriage. In the language of bargaining theory, the level of utility in the case of divorce is called threat point. (For simplicity, I only refer to the divorce-threat version of the bargaining model; another version, called separate spheres model, considers inefficient arrangements within the marriage as threat points; see Lundberg 
and Pollak, 1996). Lundberg and Pollak (2001) apply bargaining theory to family migration decisions. As in the Mincer model, a family only moves if both partners agree to the move. But clearly, a family move will shift both partners' threat points. If one partner gains from the move (e.g. yields a higher income) but the other partner loses, the threat points are shifted in favor of the first partner. He or she has a higher income and on top of that gets a better intrafamily deal. So this partner will always agree to the move. But what about the second partner? Nash-bargaining implies that the second partner will receive a smaller share after the move, but the crucial question is: a smaller share of how much? If there are net gains from migration, the second partner will receive a smaller piece of a larger pie, which can or cannot be an improvement in absolute terms. Thus, even though family income would increase after the move, the anticipated change in the intra-household resource allocation can lead to a veto by the family member whose bargaining position is weakened after the move. Because a potential increase in joint income is not realized, the family remains at an "inefficient" location. This theoretical argument actually dates back to Ott (1992), who applied it to fertility rather than migration decisions. Ott showed that opportunity costs of women who have children do not only reduce fertility, but reduce fertility to suboptimal levels. The main empirical implication of the bargaining model is that families are less mobile than the Mincer model suggests. Some moves that are beneficial in the sense that the net gains accumulated across all household members are positive will not happen when there is intra-family bargaining.

Sociologists have criticized economic models from a different perspective. They claim that the models are incomplete in the sense that they do not account for influence of gendered family roles on decision making within the family (Bielby and Bielby, 1992). In fact, both the Mincer and the bargaining model are blind to the gender of the family members who gain or lose. As long as the sum of benefits outweighs the sum of losses or as long as 
both partners gain from the move, it does not matter if the move is made to foster the husband's or the wife's career. However, empirical studies from the U.S. have long shown that family migration decisions are asymmetric in the sense that - within the group of dual earner couples - women's job characteristics do not help to explain the geographical mobility of families. For instance, Duncan and Perruci (1976) follow couples of college graduates longitudinally and find no effect of the female partner's occupational status or her relative income on the propensity to move. Lichter (1982) studies the effect of the female's occupational status, income, and work commitment on the migration probability of dualearner couples. Of eight different indicators, only seniority had a significant negative effect on the geographic mobility of a couple.

Gender ideology can explain these results as has been demonstrated in several studies. Bird and Bird (1985) report that men with egalitarian gender-role beliefs show more reluctance to accept a job offer in another region and less reluctance to move in order to foster their wives' careers than men with traditional gender-role beliefs. Women with egalitarian role-beliefs are more likely to report that a recent family move was triggered by her career concerns. They also report more willingness to accept a job offer in another region regardless of their husbands' jobs. Bielby and Bielby (1992) show that, independent of the partner's income, traditional men are more willing to move for their own career's purpose than egalitarian men, and traditional women are less willing to move than egalitarian women. But even among individuals with egalitarian gender-role beliefs, women are more reluctant to move for their own careers than men. Further, Bielby and Bielby find that, among men with traditional gender-role beliefs, the wife's income has no effect on self-reported willingness to move in benefit of their careers, whereas women with traditional gender-role beliefs become increasingly reluctant to move to benefit their careers when the income of the partner increases. 
The above findings suggest that family migration decisions are asymmetric in the sense that men dominate these decision also if their wives have a comparable labor market position, because men mostly take the primary provider role. However, many of these studies only look at the self-reported willingness to move and only few are really longitudinal and analyze the relevance of male and female characteristics for actual migration behavior. It is unclear if self-reported willingness really translates into behavior. For example, Berger, Foster, and Wallston (1978) report that even in egalitarian couples of college graduates, the female partner often eventually followed the male partner. Apparently, the men had less problems finding a job after graduating from college. This suggest that egalitarian rolebeliefs can be too costly to be acted upon. However, it is unclear how far the Berger et al. results can be generalized because their sample was small and rather selective.

In this article, I study if gender ideology matters for actual behavior using a large German representative panel data set (SOEP, see below). The question is whether traditional and egalitarian couples behave differently. Statistically, this translates into the question whether there are interaction effects between labor market characteristics - relevant for interregional mobility - of men and women in dual-earner couples and their gender ideology. More precisely, the analytical strategy is to sort couples in two groups: egalitarian and traditional couples. In egalitarian couples, husband's and wife's characteristics should have the same effect on migration behavior. Consider education as one of the most important determinants of inter-regional mobility: an egalitarian couple that consists of a highly educated husband and a less educated wife should be as mobile as a couple that consists of a less educated husband and a highly educated wife. Egalitarian couples in which both partners are highly educated should be less mobile than couples with only one educated partner, because a move potentially affects the career of the tied mover. In contrast, if gender ideology matters, only the husband's education level should affect traditional couples' 
propensity to migrate. Traditional couples that consist of a highly educated husband and a less educated wife should have a higher migration rate than couples that consist of a less educated husband and a highly educated wife, but the same migration rate as couples with two highly educated partners.

The existing literature on family migration suffers from lack of information needed for such a test of the importance of gender ideology. Either there are longitudinal data but no information on gender ideology (e.g., Jürges, 1998a), or there is good information on gender ideology but no longitudinal data (Bielby and Bielby, 1992, explaining the respondent's willingness to move).

The present paper contains two main innovations compared to earlier studies of family migration using the same data. First, I do not use "direct measures" of gender ideology such as the respondents' agreement or disagreement to items like "It is more important for a wife to help her husband's career than to have one herself", "It is much better for everyone if the husband is the wage-earner and the wife takes care of her home and family", or "A married woman should refrain from working if jobs are scarce and her husband is able to earn the family's living". Such direct measures are likely to be endogenous in the sense that individuals approve of such statements to justify the very fact that they are not working in the labor market. Instead, I will use the extensive information on time spent on household chores, both on workdays and on weekends, contained in the SOEP data. Because the husband's share in housework is often found to be larger in egalitarian couples than in traditional couples (De Laat and Sevilla-Sanz, 2004; Greenstein, 1996, 2000; Huber and Spitze, 1983), information of relative time-use is also informative on gendered family roles. This measure might be affected by covariates - such as the relative labor market position of a couple - that simultaneously influence migration behavior (Hiller, 1984). For this reason, one would feel uncomfortable using time-use on workdays. I will thus identify traditional and 
egalitarian couples by the husband's share of housework done on a typical Sunday, where housework consists of traditionally female tasks (Greenstein, 1996): washing, cooking, cleaning the house, childcare, and grocery shopping (not so common on a typical Sunday in Germany because of strict opening hours regulations). Below, I will show in some detail that housework on Sundays is much less affected by labor market characteristics and more affected by gender ideology than housework on workdays.

Another innovation is the operational definition of migration, i.e. the empirical distinction between residential mobility and migration. Due to a lack of information on migration distances, earlier studies have defined migration mainly by the motive of a move, i.e., defining all "job-related" moves as migration and all other moves as residential mobility. Fortunately, the access to regional identifiers in the SOEP has been facilitated recently, so that it is now possible to define migration more conventionally by the (approximate) distance of the move.

\section{DATA AND MEASUREMENT}

The data used in this study are drawn from the years 1985 to 2003 of the German SocioEconomic Panel (SOEP), an annual household panel survey of the private households in Germany (for a detailed description see SOEP Group, 2001; extensive documentation can be found at www.diw.de/english/sop/index.html). The data are collected in personal interviews as well as in self-completion questionnaires and contain a wide array of characteristics of all household members over the age of 16. Each individual answers his or her own questionnaire. There are thus no proxy interviews of husbands for wives or vice versa. This feature makes the SOEP particularly suitable for the analysis presented in this paper. There is not only detailed information on both husband's and wife's characteristics, the information is 
also likely to be of better quality than if there was proxy information, e.g. on the division of labor in the household.

The survey started in West Germany in 1984 with a net sample of some 6,000 households (response rate at baseline: 63\%). The sample has undergone two major extensions. In 1990, the sample was extended by some 2,200 households in East Germany. In 2000, a refreshment sample was drawn in East and West that about doubled the total sample size to 14,000 households.

The aggregate number of household-years across all sub-samples is about 150,000. For the purpose of this study, I have restricted the sample in various ways. First, for reasons explained below, I do not make use of the East German sample, which reduces the number of observations by 30,000. Second, I include only households with at least one economically active partner (self-employed, employed, or registered unemployed), reducing the sample by another 27,000 observations. Third, as is also explained below, observations in 1984 were dropped because of missing information (minus 4,600 observations). Fourth, because migration is measured as a move between two separate waves, all households that are interviewed only once or who change composition are also eliminated, i.e. couples who do not stay together across waves are dropped from the sample. The final sample has a total number of 72,472 household-years. A detailed sample description can be found in the Appendix. In all of the regressions reported below, cases with missing values have been excluded. No imputation, mean substitution, or other method to increase the number of cases in the analyses has been attempted, because item non-response is a relatively small problem in SOEP (e.g. a lot less than 5\% for time-use data). 


\section{Dependent Variable}

The literature usually distinguishes between migration and residential mobility (Rossi, 1980). Migration is defined as a long-distance move (across regional borders), whereas residential mobility is defined as a short-distance move, typically within a town or other small geographic region. Because direct information on migration distances is lacking, earlier migration studies using the SOEP have distinguished residential mobility and migration either by the self-reported migration motive (Jürges, 1998a, 1998b), mobility across broad regional borders (Hunt 2000, 2004), or by changes in the size classification of the town of residence (Büchel, 2000).

There is a clear relationship between migration motives and migration distance (Lansing and Mueller, 1967). Long-distance moves are mostly job-related, whereas residential mobility is mostly family- or housing-related. This finding justifies to restrict the analysis to job-related moves. Still, the reliability of self-reported motives to move is somewhat questionable. First, in the SOEP only one member of the household is asked. But motives might not be the same for all household members. For example, a husband who moves to accept a better job will certainly say the job was job-related if asked. His wife, the "tied mover", might beg to differ and claim that the motive was to keep the family together. Second, it is not entirely clear what respondents understand by "job-related". A sizeable number of moves for professional reasons is of rather short distance.

The definition of migration as a move across regional borders also has drawbacks. First, long-distance moves within regions can be mistaken for residential mobility. Second, short-distance moves across borders can be mistaken for migration. The relative importance of both types of errors depends on the size of the regions under consideration. The larger the regions, the greater the potential for the first type of error. For privacy reasons, the scientific use files of the SOEP contain only the federal state as place of residence. However, many of 
the 16 German federal states are far too large for a useful empirical distinction between residential mobility and migration. Households can move up to $400 \mathrm{~km}$ without crossing state borders. Short distance moves across state borders that are falsely coded as migration are presumably a smaller problem. Moreover, it can in part be dealt with by restricting the analysis to moves between non-adjacent federal states (e.g., Hunt, 2004).

Fortunately, the research potential of the SOEP has recently been increased by granting researchers restricted access to regional data on the level of districts (Kreise), of which there are currently 440. In the following, I will use this information to compute migration distances. Migration will then be defined as any move across district borders that covers at least $50 \mathrm{~km}$ (30 miles) as the crow flies. The distance between districts A and B is calculated as distance between the capitals of districts A and B, respectively. Of course, this is only an approximation of the true migration distance and there is still potential for measurement error. A distance of more than $50 \mathrm{~km}$ between district capitals does not mean that a move between the respective districts necessarily covers $50 \mathrm{~km}$. On the other hand, a few districts are quite large (especially in rural areas), with distances of $100 \mathrm{~km}$ from one end to the other. However, these are clearly exceptions.

Overall, the use of district of residence information is a major improvement compared to previous migration research with SOEP data. The main drawback is that observations of East German households had to be dropped. In the course of far-reaching regional reforms in the early 1990s, the number of East German districts has been gradually reduced from 215 to 111 , involving substantial border changes. It is thus impossible to identify reliably the moves across district borders that took place until the late nineties. 


\section{Independent Variables}

Time use and gender roles. As mentioned in the introduction, I identify traditional and egalitarian couples by differences in the husbands' share of the couples' total time spent on a usual Sunday on traditionally female household tasks. Time-use on workdays is arguably dependent on labor force participation (Hiller, 1984) and thus endogenous to the family migration decision. In contrast, time-use on weekends should be less affected by the relative position of both partners on the labor market and thus be a more useful indicator of genderroles within the household. Assuming that nobody does paid work on weekends (which will of course not always hold), the amount of housework done on weekends is also an inverse measure of the leisure enjoyed by each partner. The time-use information provided in the SOEP based on the following question: "What does a typical workday/Sunday look like for you? How many hours per day do you spend on the following activities? (Please give only whole hours. Use zero if the activity does not apply)". Respondents are then given a list of seven different types of activities: (1) Job (including commuting), (2) Errands (shopping for groceries, etc.), (3) Housework (washing, cooking, cleaning), (4) Child care, (5) Education (also school, university), (6) Repairs on and around the house, car repairs, garden work, and (7) Hobbies and other leisure activities. In my analyses, housework includes (2), (3), and (4). Because time-use on Sundays is only available about every other year, I use the households' information given in preceding waves where it is not available.

In the empirical analysis of dual-earners' migration behavior, I split the sample of dual-earner couples so that about one third of all couples are labeled "egalitarian" and two thirds are labeled "traditional". The corresponding threshold is $37.5 \%$, i.e., all couples in which the male partner's share in housework on a typical Sunday is at least $37.5 \%$ are classified as egalitarian. Note that this value is quite close to what couples perceive as a fair division of housework (Lennon and Rosenfeld 1994). Couples usually do not define a 50-50 
split as fair. Rather, men consider a male share of $36 \%$ as fair, whereas consider a female share of $66 \%$ as fair. Still, one might argue that the sample split at $37.5 \%$ is artificial, and that results will depend on which threshold is chosen. I have thus studied the sensitivity of my results presented below by using two alternative thresholds: one low value, with a male share of housework of $25 \%$, and one high value with a share of housework of $50 \%$. As it turns out, the main results do not depend on the choice of the threshold.

Education. Education is measured as the number of years of education. It is probably the most important determinant of migration behavior. This is not only because the labor market for highly educated individuals is more dispersed geographically than the labor market for the less educated. Also, social networks of highly educated people are more dispersed geographically than those of the less educated (Fischer 1982). The first information on a vacancy is often provided by friends or relatives (Granovetter 1974). The better educated thus also have better information on jobs in other regions.

In the German context, it is common practice to compute years of education as the sum of years it usually takes to achieve the highest educational degree reported by a respondent, for example 10 years for lower secondary school, 11.5 years for lower secondary school plus apprenticeship. 13 years for upper secondary school, or 18 years for university. When analyzing the migration behavior of couples, it is important to study educational achievement of men and women in relation to each other. In some analyses, education years of both partners are thus dichotomized at 12 years of education and combined to reflect the education level of the couple. This variable has four different categories: (1) both partners have less than 12 education years, (2) only male partner has 12 or more education years, (3) only female partner has 12 or more education years, (4) both partners have 12 or more education years. In the regression analyses, the first category is used as baseline. 
Seniority. The second important job-related characteristic used in the present study is seniority, measured as the number of years a respondent works with the same employer. Seniority reflects the amount of employer-specific human capital that a worker has accumulated and thus measures the costs of giving up a job and changing employers. Again, for couples, the variable is dichotomized and combined in a single variable with four categories: (1) both partners are working less than 5 years with their current employer, $(2,3)$ only male/female partner is working less than 5 years with the same employer, (4) both partners are working at 5 or more years with their current employer.

\section{Control variables}

As household level control variables I use home ownership, household size, years of residence in the present house or apartment, an indicator variable for marital status (where 1 $=$ married), and an indicator variable for urban areas (cities with more than 100,000 inhabitants) - all variables are known to be important determinants of migration behavior (see Greenwood, 1975, 1997; Lansing and Mueller, 1967). In descriptive analyses of the division of household labor, I also use individual wages, computed as annual labor earnings divided by hours worked, and per capita household income, computed as total annual household income from all sources divided by the number of household members.

\section{RESULTS}

\section{Descriptive results}

Migration. Table 1 shows the distribution of migration distances by self-reported (main) motive for all households. Until 1996, Respondents were asked to report the main reason for their most recent move. Since then it is possible to report more than one reason. If more than 
one reason was given, I have assumed the following hierarchy of reasons: job, housing, family, other. The first column shows moves for job reasons. Although only $13.5 \%$ of all moves are made for job reasons, they account for $64.9 \%$ of all long-distance moves, i.e. moves that cover more than $50 \mathrm{~km}$. The average distance of job-related moves across district borders is $180 \mathrm{~km}$.

$<$ about here Table 1>

The most frequent self-reported motive is housing (e.g. respondents acquired or inherited a house or apartment, the former apartment was too small, too large, too expensive, poorly equipped, or badly located), accounting for $56 \%$ of all moves but only for $12.2 \%$ of all long-distance moves. $87.9 \%$ of housing-related moves take place within district borders, and another $9.7 \%$ are shorter than $50 \mathrm{~km}$ although district borders were crossed. The average distance of across border moves is $50 \mathrm{~km}$. Family reasons (marriage, divorce, move out of parental household) are the second most important motive both for moves in general and for long-distance moves. About $9 \%$ of these moves are long-distance, accounting for $15.7 \%$ of all long-distance moves. The average migration distance is $96 \mathrm{~km}$. There is still a sizeable number of moves with "other" reasons: respondents have been given notice by their landlords, rented apartments were converted to owned apartments, and other unspecified reasons. These other moves are predominantly within district borders.

Table 2 shows annual migration rates and average migration distances by household type. Unsurprisingly, single households - who have an annual inter-district mobility rate of about $2 \%$ - are more mobile than couples. Couples are much less mobile, which is in line with the basic hypothesis of the Mincer family migration model. The annual migration rate of couples with a man in the labor force is $.54 \%$, a bit smaller than the migration rate of dualearner couples (.63\%). The least mobile household type are couples in which only the wife is in the labor force $(.17 \%)$. These are mostly women with husbands who are already retired. 
$<$ about here Table $2>$

Time use. Table 3 contains the average self-reported number of hours spent on household chores, shopping for groceries and childcare "on a usual workday" and "on a usual Sunday". Figures are computed separately for men and women, for households with and without children, and for different household types (singles, single-earner couples, dual-earner couples). Because time-use on weekends is not available in each year of the SOEP the number of observations is smaller than for time-use on workdays. There are several noteworthy findings in Table 3:

- Men spend considerably less time on housework, shopping and childcare than women. The average share is about $30 \%$. Even if the husband is not in the labor force (but the wife is), he spends less time on these tasks than his wife ( 37 to $47 \%$ on workdays and 25 to $31 \%$ on Sundays).

- The difference between men and women living in couples is larger than the difference between single men and women, although the sum of hours is about the same. For example, on a typical workday, single men without children spend on average 2.1 hours on housework and single women without children spend on average 2.8 hours on housework. In dual-earner couples without children, men spend only 1.4 hours on housework but women spend 3.7 hours. Intra-household division of work primarily benefits men.

- Men who are working tend to increase their share of housework on Sundays, particularly if the couple has children. For instance, husbands with children who are single earners increase their share from $14.1 \%$ to $25.3 \%$, and husbands in dual-earner couples increase their share from $20.7 \%$ to $28.4 \%$. In childless couples, the increase is smaller (from $14.8 \%$ to $17.5 \%$ ) if the husband is a single earner, or negative but small in dual-earner couples (from $27.7 \%$ to $26.6 \%$ ). 
$<$ about here Table $3>$

Table 3 does not allow to conclude that hours spent on workdays and on weekends are inherently different. This is demonstrated in Table 4, which contains the results of regressions of the male housework share in dual-earner couples on a number of explanatory variables (Beblo, 1999; Hersch and Stratton, 1994).

Housework sharing arrangements on workdays obviously depend on labor force characteristics. High wage men share less of the housework burden on workdays. The same holds for high wage women. The effects are symmetric in the sense that (independent of the partner's sex) higher wages decrease the share in housework by about the same amount. Hence, a one unit increase in the wage rate of both partners leaves the male partner's share of household work unchanged. Highly educated men share less of the housework burden on workdays, and men with highly educated women contribute more to the housework on workdays than others. If the number of years of education of both male and female partner rises by one, the male partner's share rises (significantly). Finally, if the couple is married or if the couple has children, the husband's share drops by 4 to 5 percentage points.

$<$ about here Table 4>

The second model describes determinants of division of work on Sundays. Some general characteristics like age (or cohort), marital status or the year of the interview have similar effects on housework sharing arrangements on workdays and Sundays. However, there are also interesting differences: the effect of the female wage rate becomes somewhat weaker, whereas the effect of male wage rate vanishes completely. Male labor market characteristics thus appear to have much less effect on the division of work on Sundays. Interestingly, the sign of the effect of male education changes from negative to positive. Better educated men do a larger share of Sunday's housework than the less educated but the 
effect of female education remains more or less unchanged. The combined effect of male and female education is roughly twice as large on weekends than on workdays. Given that education and egalitarian values are correlated (Inglehart and Norris, 2003), these findings are consistent with the claim that the intra-household division of work on workdays depends largely on labor force characteristics of men and women, whereas the division of work on Sundays tends to be determined by gendered family roles. Of course, the empirical difference between workdays and Sundays may be somewhat blurred because of "spill-overs" from workdays to weekends if part of the housework is shifted to weekends.

\section{Migration models}

Because the SOEP contains panel data, it seems appropriate to account for repeated observations by estimating panel regression models, i.e. fixed or random effects models (see e.g. Baltagi 1995). The binary regression counterpart to a fixed effects model is the conditional logit model. Unfortunately, the conditional logit model is not useful in the present application, because only households that have variation in the dependent variable, i.e. that move at least once, contribute to the likelihood function. The large number of households that never migrated during the observation period would thus drop out of the estimation, which is obviously not useful. The alternative is to estimate a random effects probit model. As the random effects alternative to conditional logit, I have estimated each of the models below as a random effects probit model. Apart from the fact that the random effects model rests on the critical assumption that the individual effect is uncorrelated with the other regressors - an assumption that is not often met in applied work - the estimated intra-household correlation coefficients were close to zero so that the other parameters were comparable to estimates using pooled data. I have thus decided to report only results from pooled logit regressions - however with standard errors that account for the fact that 
households are repeatedly observed. Another issue that has to be taken care of is the fact that regional mobility is a major source of panel attrition. The regression results presented below account partly for panel attrition by using longitudinal weights. These weights (essentially inverse attrition probabilities) are available with the data.

Single men and women. Despite the main interest in the mobility of couples, it is instructive to start by comparing the migration behavior of men and women who do not live with a partner. Single men and women might be viewed as unconstrained optimizers for whom the individual microeconomic migration model has a higher relevance than for couples. The comparison will yield insight into the main determinants of individual migration behavior serve as a starting point for the analysis of couples' migration behavior. Table 2 has shown that the average annual migration rates of single men and women are very similar $(2.07 \%$ versus $2.08 \%$ ) and not significantly different. However, this result could be a matter of chance when different forces neutralize each other. It does not necessarily mean that men and women behave in the same way. Such a statement would only be warranted if the effects of important covariates on migration behavior have about the same size.

$<$ about here Table 5>

Table 5 contains the results of logistic regressions of the probability of making a move of more than $50 \mathrm{~km}$ between two waves, separately for single men and women. Apart from general household characteristics that are known to affect inter-regional mobility, such as home ownership, length of residence, age, household size, or city size, I have included the number of education years and the number of years with the current employer (seniority) as explanatory variables. I also control for a linear time trend. The results are mostly in line with results known from the literature. Regional mobility depends negatively on home ownership, length of residence, age, household size (measured by the presence of children), and seniority (measured as the number of years working with the current employer). Individuals living in 
urban areas move less often than others, and finally, education has a strong positive effect on the propensity to migrate.

The main question, however, is whether these variables have differential effects on the mobility of men and women. This proves not to be the case. The null hypothesis of a chisquared test that the parameters of the separate models are jointly equal cannot be rejected $\left(\chi^{2}(9)=8.97\right)$. Even when compared individually, no parameter shows significant sex differences (the effect of length of residence is significantly different only at $p=0.11$ ). In other words: I find no major gender differences in the migration determinants of single men and women, in particular not with respect to job-related characteristics such as education or seniority. As we will see next, this result stands in sharp contrast to models for dual-earner households, where male and female characteristics have distinctly different effects on migration probabilities, at least in traditional couples. Gender differences found in couples must thus be attributed to some interaction of husband and wife's characteristics.

Dual-earner couples. In Table 6, I show the logistic regression results for dual-earner couples, separately for traditional and egalitarian couples. In addition to general household characteristics, I include the number of education years and the number of years with the current employer (seniority) of both spouses as explanatory variables.

$<$ about here Table 6>

In the first two models, the estimated parameters of education show some noteworthy differences. In traditional couples, only the husbands' years of education have a significant and positive effect on mobility. The wife's years of education have virtually no effect on migration probabilities, and the coefficients of male and female years of education are statistically different from each other $\left(\chi^{2}(1)=8.61\right)$. This relationship is somewhat reversed in egalitarian couples: the effect of husband's years of education on mobility is smaller than 
the effect of the wife's years of education. The education parameters are jointly significant $\left(\chi^{2}(2)=36.4\right)$, but not significantly different from each other $\left(\chi^{2}(1)=0.34\right)$.

Of course, husband's and wife's education are highly correlated (Blossfeld and Timm, 2003) and the parameters just discussed might not correctly identify each single effect.

Models 3 and 4 - that contain male and female education in relation to each other - shed more light on this issue. As explained above, men's and women's education and seniority are dichotomized and interacted. The new variable has four categories, and thus enters the regression as a set of three dummy variables. Table 7 serves to illustrate the coding of joint variables and the tests discussed in the remainder of this section. In the following, let $\alpha, \beta$, and $\gamma$ denote the estimated logit coefficients of the respective dummy variables, e.g. $\alpha$ denotes the logit coefficient for a low male/high female education couple relative to the baseline category (low male/low female education couples).

$<$ about here Table 7>

In traditional couples (model 3), the effect of high male education is positive and significant, independent of the education level of the female partner $(\beta=1.42$ when the wife has low education, $\gamma-\alpha=1.36$ when the wife has high education). The coefficients of high male education categories are not statistically different $\left(\chi^{2}(1)=0.20\right)$. In contrast, the effect of high female education in traditional couples is not statistically different from zero. This holds independently of the education level of the male partner (logit coefficients are $\alpha=$ 0.07 when the husband has low education and $\gamma-\beta=-0.13$ when the husband has high education). To summarize, in traditional couples, female education has no effect on the probability of a family move. A very similar pattern is found in a recent study using date from the Panel Study of Income Dynamics (PSID; see Compton and Pollak, 2004), although the authors do not consider gendered family roles. 
The analysis for egalitarian couples (model 4) reveals striking differences. Now, both male and female education have a positive effect on regional mobility. The coefficient for female education is even larger than the coefficient for male education $(\alpha=1.33$ and $\beta=1.03$, respectively), but not statistically different $\left(\chi^{2}(1)=.50\right)$. Furthermore, egalitarian couples with two highly educated individuals are more mobile than egalitarian couples with only one highly educated partner $(\gamma=1.39)$. However, if both partner's education had an independent effect on mobility, adding up both effects should yield the coefficient of a couple with two highly educated partners. However, this is not the case. Statistically, the logit coefficient for couples with two highly educated partners is significantly smaller than the sum of coefficients of couples with only one highly educated partner $\left.(\alpha+\beta=2.36) ; \chi^{2}(1)=3.47\right)$, but the differences between $\gamma$ and either $\alpha$ and $\beta$ are not significant. Having a highly educated partner does thus not increase the mobility of a highly educated respondent. It must be stressed, however, that this holds only for egalitarian couples and not for all couples (as the Mincer model predicts). In traditional couples, having a highly educated husband significantly increases the migration propensity of a highly educated wife.

An alternative to migration often chosen by highly educated dual-earner couples is commuting. Table 8 - which shows average combined commute-to-work distances in $\mathrm{km}$ by education and implied gender-role beliefs - illustrates this point. Egalitarian couples travel greater distances to work, independent of their education level. The type of couple that commutes the greatest distances to work are egalitarian high education couples.

$<$ about here Table $8>$

Going back to Table 6 , the results for seniority are not as clear cut as those for education years. In traditional couples, seniority seems to be no major migration obstacle, except when both partners are employed 5 years or more with their current employer $(\gamma=$ - 
0.68). In egalitarian couples, male seniority appears to exert a stronger influence on migration probabilities $(\beta=-0.73)$ than female seniority $(\alpha=-0.16)$, but the differences are not significant. As in traditional couples, seniority has the strongest effect when both partners are employed for 5 or more years with their current employer $(\gamma=-1.37)$.

As already mentioned, I have studied the sensitivity of my results to the choice of the traditional/egalitarian threshold in the husband's housework share. I estimated all models with two alternative thresholds: one low value, with a male share of housework of $25 \%$, and one high value with a share of housework of 50\%. The results - shown in the Appendix - are qualitatively similar to those above.

\section{DISCUSSION}

In the present paper, I have presented evidence on the determinants of the inter-regional mobility of West German households and families using the German SOEP. Long-distance moves are predominantly job-related. About two thirds of the migrants in my sample reported job reasons as the main motive for their move. However, in dual-earner couples, two jobs are affected by migration decisions. A move that benefits the job prospects of one partner may harm the prospects of the other partner. Economic and sociological models of family migration behavior differ in their assessment of how these costs and benefits affect migration behavior.

Earlier literature from the U.S. has convincingly shown that gender ideology, i.e. beliefs about who in a couple should be the primary provider, are good predictors for the reported willingness to move for job-related reasons although the move may harm one's partner's job prospects (Bielby and Bielby, 1992). Still, there is shortage of evidence that 
gender ideology matters for actual migration behavior. The present paper aimed to fill that gap.

One innovation of this study was to use data on the division of labor within the household on a typical Sunday rather than attitudinal data to identify traditional and egalitarian couples. Previous research from the U.S. has shown that the husbands' percentage of total hours spent on traditionally female household tasks is strongly related to gender ideology (Greenstein, 1996). Greenstein found that the division of household labor reaches equality only if both partners hold egalitarian ideologies. My research strategy drew on this finding when the sample was divided into traditional households (where the husband's share is below a certain threshold) and egalitarian households (where the husband's share is above a certain threshold). The rationale to use time-use on weekends was to get a measure that is (roughly) independent of hours worked on the labor market.

The analysis of migration behavior proceeded in two steps: as a preparatory step, I studied whether the migration behavior of single men and women (who are in some sense "unconstrained" optimizers) is the same. The answer was no. I found no gender difference in the main determinants of inter-regional migration of singles. This is an important finding because it suggests that there are no fundamental gender differences in migration behavior. The next step was to split the sample of dual-earner household into "traditional" and "egalitarian" couples, as described above. I estimated separate regression models for both groups to explain their inter-regional mobility. The main result was that education (as one of the major determinants of inter-regional mobility) affects migration behavior differently in the two sub-samples. In the traditional sub-sample, only the husband's education has an effect on the propensity to migrate - independent of the wife's level of education, which has no effect at all. In the egalitarian sub-sample, husband's and wife's education affect migration in the same manner. The highly educated are more mobile than others - if their partner has a 
low education level, but a high education level decreases mobility if the partner also has a high education level. This symmetry suggests that both partners' careers are taken into account in migration decisions when couples' gender ideologies are egalitarian rather then traditional. The results presented in this paper thus support the hypothesis that gender ideology matters for the actual migration behavior of German dual-earner couples.

The main limitation of the current study is that, despite the large sample size, the number of migrant households is small. According to the operational definition chosen, only 182 dual-earner couples are movers, which corresponds to an annual migration rate of .59\%. The true proportion of migrant households is likely to be higher, because households systematically drop out of the panel when they move and their new addresses remain unknown. The small number of migrant households entails two problems. One is that little variation in the dependent variable affects the precision of the regression estimates. With more migrant households in the sample, some of the insignificant coefficients or differences between coefficients might have turned statistically significant. It is less obvious, however, whether that would have affected the substantive results. A related disadvantage of the small number of migrants is that the binary regression model has to be specified rather parsimoniously. Adding further job-related variables that capture potential migration costs and benefits but that are not crucial to the analysis will inflate standard errors of all estimates and increase the possibility of separating the model (see Hosmer and Lemeshow, 2000). A second worry is that households who move to a new unknown address are a selective group and their exclusion from the sample might bias the results. To check the sensitivity of the results I have included all households who moved to an unknown address as movers. This did not change the results presented above.

Another limitation of the present article is that time-use (and thus division of household labor) on weekends was not available in each single survey year. The solution to 
substitute the values in years without that information with data from preceding waves might raise objections. Although gender ideology is probably stable over periods of one or two years, the division of labor can change because of intervening events such as the birth of a child or changes in employment status. Table 2 gives some idea about how much the division of labor changes. For instance, the presence of children increases the husband's share of hours spent on housework by 1.7 percentage points. In my analysis of migration behavior I have dichotomized the sample at different thresholds. The proportion of households who would change categories in response to childbirth is thus very low (approximately 0.7 percentage points) and it is unlikely that the main results are affected. Moreover, restricting the analysis only to those years in which Sunday data is available does not affect the results.

Given the small number of migrants in the present study, several directions for future research come into mind. One possibility is to increase the number of migrant households on which to draw conclusion is to collect data from a representative sample of recent migrants, and to combine this data with a sample that contains non-migrants and migrants (see Bover and Arellano, 2002). Further. it would be extremely valuable if the study was replicated with data from other countries. A recent study by Compton and Pollak (2004) shows that similar results can be expected for example using the U.S. PSID. Household panel surveys now exist in a number of countries, but they do not exist as long as the PSID so that each nationally representative data set alone is likely to suffer from a small number of migrant households. Pooling several available data sets might thus be an attractive option. 


\section{REFERENCES}

Baltagi, B. H. 1995. Econometric Analysis of Panel Data. New York, Wiley

Beblo, M. 1999. "How Do German Couples Spend Their Time? A panel data analysis." DIWVierteljahrshefte zur Wirtschaftsforschung, 68:146-52.

Berger, M., M. Foster, and B. S. Wallston. 1978. "Finding Two Jobs." In: Working Couples, edited by Rapoport R. and R.N. Rapoport. London: Routledge.

Bielby, W. T. and D. D. Bielby. 1992. "I Will Follow Him: Family Ties, Gender-role Beliefs, and Reluctance to Relocate for a Better Job." American Journal of Sociology 97:1241-67.

Bird, G. A. and G. W. Bird. 1985. "Determinants of Mobility in Two-Earner Families: Does the Wife's Income Count?" Journal of Marriage and the Family 47:753-8.

Blossfeld, H.-P. and A. Timm. 2003. Who Marries Whom? Educational Systems as Marriage Markets in Modern Societies (European Studies of Population, Vol 12). Dordrecht, Kluwer Academic Publishers.

Bover, O. and M. Arellano. 2002. "Learning about migration decisions from the migrants: using complementary datasets to model intra-regional migrations in Spain." Journal of Population Economics 15:357-80.

Boyle, P., T. J. Cooke, K. Halfacree, and D. Smith. 2001. "A Cross-national Comparison of the Impact of Family Migration on Women's Employment Status." Demography $38: 201-13$

Büchel, F. 2000. "Tied Movers, Tied Stayers: The Higher Risk of Overqualification among Married Women in West Germany." In: Gender and the Labour Market. Econometric Evidence of Obstacles to Achieving Gender Equality, edited by S. S. Gustafsson and D. E. Meulders. New York, Macmillan. 
Compton, J. and R.A. Pollak. 2004. "Why Are Power Couples Increasingly Concentrated in Large Metropolitan Areas?" NBER Working Paper 10918.

DaVanzo, J. 1976. Why Families Move: A Model of the Geographic Mobility of Married Couples. Santa Monica: RAND.

DaVanzo, J. 1981. "Microeconomic Approaches to Studying Migration Decisions." In: Migration Decision Making, edited by G.F. De Jong and R.W. Gardner. New York, Pergamon Press.

De Laat, J. and A. Sevilla-Sanz. 2004. "Working Women, Husband's Home Time, and Lowest-Low Fertility in Europe." Paper presented at the $18^{\text {th }}$ Annual Conference of the European Society for Population Economics, Bergen.

Duncan, R. P. and C. C. Perucci. 1976. "Dual Occupation Families and Migration." American Sociological Review 41:252-61.

Fischer, C. S. 1982. To Dwell Among Friends. Chicago, Chicago University Press.

Granovetter, M. S. 1974. Getting a Job. A Study of Contacts and Careers. Cambridge, MA, Harvard University Press.

Greenstein, T. 1996. "Husbands' Participation in Domestic Labour: Interactive Effects of Wives' and Husbands' Gender Ideologies." Journal of Marriage and the Family 58:585-95.

Greenstein, T. 2000. "Economic Dependence, Gender, and the Division of Labor in the Home: A Replication and Extension." Journal of Marriage and the Family 62:322-35.

Greenwood, M. J. 1975. "Research on Internal Migration in the United States: A Survey." Journal of Economic Literature 13:397-433.

Greenwood, M. J. 1997. "Internal Migration in Developed Countries." In: Handbook of Population and Family Economics, edited by M.R. Rosenzweig and O. Stark, Amsterdam, Elsevier. 
Hersch, J. and L.S. Stratton. 1994. "Housework, Wages, and the Division of Housework time for Employed Spouses." American Economic Review 84 (Papers and Proceedings): $120-5$

Hiller, D. V. 1984. "Power dependence and the division of family work." Sex Roles 10:100319.

Hosmer, D. W. and S. Lemeshow, S. 2000. Applied logistic regression, $2^{\text {nd }}$ ed. New York, Wiley

Huber, J., and G. Spitze. 1983. Sex stratification: Children, housework, and jobs. New York, Academic Press.

Hunt, J. 2000. "Why Do People Still Live in East Germany?" NBER Working Paper 7564.

Hunt, J. 2004. "Are Migrants More Skilled Than Non-Migrants? Repeat, Return and Same Employer Migrants." DIW Discussion Paper 422.

Inglehart, R. and P. Norris. 2003. Rising Tide: Gender Equality and Cultural Change Around the World. Cambridge, Cambridge University Press.

Jürges, H. 1998a. "Beruflich bedingte Umzüge von Doppelverdienern" [Job-related Geographic Mobility of Dual-Earner Couples]. Zeitschrift für Soziologie 27:358-77.

Jürges, H. 1998b. "Einkommen und berufliche Situation von Doppelverdienern nach Umzügen" [Income and Job Characteristics of Dual Earners After Migration]. Mitteilungen aus der Arbeitsmarkt- und Berufsforschung 31:234-43.

Lansing, J. B. and E. Mueller. 1967. The Geographic Mobility of Labor. Ann Arbor, Institute for Social Research, University of Michigan.

Lennon, M.C. and S. Rosenfeld. 1994. "Relative fairness and the division of housework: The importance of options." American Journal of Sociology 100:506-31.

Lichter, D. T. 1982. "The Migration of Dual-Worker Families: Does the Wife's Job Matter?" Social Science Quarterly 63:49-57. 
Lichter, D. T. 1983. "Socioeconomic Returns to Migration Among Married Women." Social Forces 62:487-503.

Long, L. H. 1974. "Women's Labour Force Participation and the Residential Mobility of Families." Social Forces 52:342-8.

Lundberg, S. and R.A. Pollak. 1996. "Bargaining and Distribution in Marriage." Journal of Economic Perspectives 10:139-58

Lundberg, S. and R. A . Pollak. 2001. "Efficiency in Marriage." NBER Working Paper 8642. Manser, M. and M. Brown. 1980. "Marriage and Household Decision Making. A Bargaining Analysis." International Economic Review 21:31-44.

Maxwell, N. L. 1988. "Economic Returns to Migration: Marital Status and Gender Differences." Social Science Quarterly 60:108-21.

McElroy, M. B. and M. J. Horney. 1981. "Nash Bargained Household Decisions." International Economic Review 22:333-49.

Mincer, J. 1978. "Family Migration Decisions." Journal of Political Economy 86:749-773.

Morrison, D. R. and D.T. Lichter. 1988. "Family Migration and Female Employment: The Problem of Underemployment among Married Women." Journal of Marriage and Family 50: 161-72.

Nivalainen, S. 2004. "Determinants of Family Migration: Short Moves vs. Long Moves." Journal of Population Economics 17:157-75.

Ott, N. 1992. Intrafamily Bargaining and Household Decisions. Berlin, Springer.

Ross, E. A. 1921. Principles of Sociology. New York. Century

Rossi, P. H. 1980. Why Families Move, $2^{\text {nd }}$ ed. Beverly Hills. Sage.

Sandell, S. H. 1977. "Women and the Economics of Family Migration." Review of Economics and Statistics 59:406-14. 
Shihadeh, E. S. 1991. "The Prevalence of Husband-Centered Migration: Employment Consequences for Married Mothers." Journal of Marriage and the Family 53:432-44.

Sjaastad, L. A.. 1962. "The Costs and Returns of Human Migration." Journal of Political Economy 70:80-93.

SOEP Group. 2001. "The German Socio-Economic Panel (SOEP) after more than 15 years Overview." Vierteljahrshefte zur Wirtschaftsforschung 70:7-14.

Spitze, G. 1984. "The Effect of Family Migration on Wives' Employment: How Long Does It Last?" Social Science Quarterly 65:21-36. 
Table 1. Percentage of moves within and across districts and average migration distances by self-reported motive; all households

\begin{tabular}{lcccc}
\hline & \multicolumn{4}{c}{ Motive } \\
\cline { 2 - 5 } Type of move & Job & Housing & Family & Other \\
\hline Total number of moves & 791 & 3,268 & 1,062 & 721 \\
\% of all moves & 13.5 & 56.0 & 18.2 & 12.3 \\
\% of moves with $d>50 \mathrm{~km}$ & 64.9 & 12.2 & 15.7 & 7.2 \\
Within district & 30.5 & 87.9 & 76.0 & 85.9 \\
Between districts; $d<50 \mathrm{~km}$ & 18.3 & 9.7 & 14.8 & 7.9 \\
Between districts; $d \geq 50 \mathrm{~km}$ & 51.2 & 2.3 & 9.2 & 6.2 \\
& & & & \\
Average between district distance $(\mathrm{km})$ & 180 & 50 & 96 & 103 \\
\hline Source: SOEP 1985-2003 & & &
\end{tabular}


Table 2. Migration rates and average distances, by household type; all moves $>50 \mathrm{~km}$

\begin{tabular}{lccccc}
\hline & \multicolumn{5}{c}{ Household type } \\
\cline { 2 - 6 } & $\begin{array}{c}\text { single man } \\
\text { in labor } \\
\text { force }\end{array}$ & $\begin{array}{c}\text { single } \\
\text { woman in } \\
\text { labor force }\end{array}$ & $\begin{array}{c}\text { couple, man } \\
\text { in labor } \\
\text { force }\end{array}$ & $\begin{array}{c}\text { couple, } \\
\text { woman in } \\
\text { labor force }\end{array}$ & $\begin{array}{c}\text { couple, both } \\
\text { in labor } \\
\text { force }\end{array}$ \\
\hline Annmary statistics & 2.07 & 2.08 & 0.54 & 0.17 & 0.63 \\
Avg. migration distance $(\mathrm{km})$ & 223 & 211 & 219 & 312 & 203 \\
Number of observations & 9,122 & 10,920 & 15,015 & 2,370 & 33,045 \\
\hline
\end{tabular}

Source: SOEP 1985-2003 
Table 3: Average number of hours spent on housework, shopping, and childcare, by type of household and type of day

\begin{tabular}{|c|c|c|c|c|c|c|c|c|}
\hline \multirow[b]{2}{*}{ Household type } & \multicolumn{4}{|c|}{ Workdays } & \multicolumn{4}{|c|}{ Sundays } \\
\hline & Men & Women & $\begin{array}{l}\text { Men's } \\
\text { Share }\end{array}$ & $\mathrm{n}$ & Men & Women & $\begin{array}{l}\text { Men's } \\
\text { Share }\end{array}$ & $\mathrm{n}$ \\
\hline \multicolumn{9}{|l|}{ Without children } \\
\hline Single man in lf & 2.1 & & & 8,273 & 1.4 & & & 4,662 \\
\hline Single woman in lf & & 2.8 & & 7,990 & & 1.9 & & 4,406 \\
\hline Couple, man in lf & 1.1 & 6.3 & $14.8 \%$ & 5,545 & 0.7 & 3.1 & $17.5 \%$ & 3,393 \\
\hline Couple, woman in lf & 2.6 & 4.0 & $37.0 \%$ & 2,002 & 1.0 & 2.6 & $24.7 \%$ & 1,076 \\
\hline Couple, both in lf & 1.4 & 3.7 & $27.7 \%$ & 15,722 & 1.0 & 2.6 & $26.6 \%$ & 8,966 \\
\hline \multicolumn{9}{|l|}{ With children } \\
\hline Single man in lf & 3.1 & & & 849 & 5.4 & & & 431 \\
\hline Single woman in if & & 8.5 & & 2,930 & & 8.7 & & 1,538 \\
\hline Couple, man in lf & 2.1 & 11.7 & $14.1 \%$ & 9,470 & 3.8 & 9.4 & $25.3 \%$ & 6,318 \\
\hline Couple, woman in lf & 6.7 & 6.6 & $47.6 \%$ & 368 & 4.2 & 8.1 & $31.1 \%$ & 220 \\
\hline Couple, both in if & 2.5 & 9.3 & $20.7 \%$ & 17,323 & 3.9 & 8.5 & $28.4 \%$ & 9,723 \\
\hline
\end{tabular}

Source: SOEP 1985-2003 
Table 4. Regression analysis predicting husband's share in time spent on housework in dual-earner couples, by type of day

\begin{tabular}{|c|c|c|c|c|c|c|}
\hline \multirow[b]{2}{*}{ Covariate } & \multicolumn{3}{|c|}{$\begin{array}{c}\text { Model } 1 \\
\text { Workdays }\end{array}$} & \multicolumn{3}{|c|}{$\begin{array}{l}\text { Model } 2 \\
\text { Sundays }\end{array}$} \\
\hline & B & SE B & $\beta$ & $\mathrm{B}$ & SE B & $\beta$ \\
\hline Average age & -0.38 & 0.03 & $-0.18^{* *}$ & -0.50 & 0.04 & $-0.19 * *$ \\
\hline Age difference & 0.09 & 0.06 & $0.02 * *$ & -0.04 & 0.07 & -0.01 \\
\hline Male education & -0.12 & 0.12 & $-0.02 *$ & 0.38 & 0.15 & $0.04^{* *}$ \\
\hline Female education & 0.71 & 0.13 & $0.09 * *$ & 0.68 & 0.17 & $0.07 * *$ \\
\hline Male wage & -0.12 & 0.02 & $-0.06^{* *}$ & 0.02 & 0.03 & -0.01 \\
\hline Female wage & 0.10 & 0.02 & $0.04^{* *}$ & 0.08 & 0.03 & $0.03 * *$ \\
\hline Married & -3.93 & 0.71 & $-0.07 * *$ & -4.59 & 1.08 & $-0.06^{* *}$ \\
\hline Children in household & -4.98 & 0.53 & $-0.13^{* *}$ & 1.66 & 0.67 & $0.03^{* *}$ \\
\hline Per capita hh income (1000s) & 0.09 & 0.04 & $0.04 * *$ & -0.04 & 0.06 & -0.01 \\
\hline Time trend & 0.14 & 0.04 & $0.04 * *$ & 0.29 & 0.05 & $0.06^{* *}$ \\
\hline Constant & 38.51 & 1.76 & & 37.26 & 2.28 & \\
\hline Number of observations & \multicolumn{3}{|c|}{20,910} & \multicolumn{3}{|c|}{12,254} \\
\hline Number of households & \multicolumn{3}{|c|}{4,756} & \multicolumn{3}{|c|}{3,798} \\
\hline$R^{2}$ & \multicolumn{3}{|c|}{.080} & \multicolumn{3}{|c|}{.074} \\
\hline$F$ & \multicolumn{3}{|c|}{$62.52 * *$} & \multicolumn{3}{|c|}{$47.57 * *$} \\
\hline
\end{tabular}

Note: standard errors corrected for multiple observations on household level

Age difference $=$ husband's age minus wife's age

$* p<.10 ; * * p<.05$ 
Table 5. Logistic regression analysis predicting single households' propensity to migrate, by gender

\begin{tabular}{|c|c|c|c|c|c|c|}
\hline \multirow[b]{2}{*}{ Covariate } & \multicolumn{3}{|c|}{ Men } & \multicolumn{3}{|c|}{ Women } \\
\hline & Coeff. & $\mathrm{SE}$ & Odds ratio & Coeff. & $\mathrm{SE}$ & Odds ratio \\
\hline Home owner & -1.25 & 0.33 & $0.29 * *$ & -0.73 & 0.35 & $0.48 * *$ \\
\hline Lengh of residence & -0.01 & 0.02 & 0.99 & -0.05 & 0.02 & $0.95^{* *}$ \\
\hline Age & -0.03 & 0.01 & $0.97 * *$ & -0.03 & 0.01 & $0.97 * *$ \\
\hline Children present & -0.90 & 0.54 & $0.40^{*}$ & -0.78 & 0.21 & $0.46^{* *}$ \\
\hline Urban area & -0.07 & 0.05 & $0.93 *$ & -0.10 & 0.04 & $0.90 * *$ \\
\hline Education years & 0.15 & 0.03 & $1.16^{* *}$ & 0.19 & 0.03 & $1.20 * *$ \\
\hline Seniority & -0.06 & 0.02 & $0.94 * *$ & -0.07 & 0.02 & $0.93 * *$ \\
\hline Time trend & 0.02 & 0.02 & 1.02 & -0.01 & 0.01 & 0.99 \\
\hline Constant & -3.66 & 0.42 & & -3.54 & 0.42 & \\
\hline Number of observations & \multicolumn{3}{|c|}{8,753} & \multicolumn{3}{|c|}{10,266} \\
\hline Number of individuals & \multicolumn{3}{|c|}{2,192} & \multicolumn{3}{|c|}{2,388} \\
\hline Log-likelihood & \multicolumn{3}{|c|}{-868.17} & \multicolumn{3}{|c|}{-982.27} \\
\hline Model $\chi^{2}$ & \multicolumn{3}{|c|}{$173.46^{* *}$} & \multicolumn{3}{|c|}{$280.12^{* *}$} \\
\hline
\end{tabular}

Note: standard errors corrected for multiple observations on household level $* p<.10 ; * * p<.05$ 
Table 6. Logistic regressions predicting the geographical mobility of dual-earner couples

\begin{tabular}{|c|c|c|c|c|c|c|c|c|c|c|c|c|}
\hline \multirow[b]{2}{*}{ Covariate } & \multicolumn{3}{|c|}{$\begin{array}{c}\text { Model } 1 \\
\text { Traditional Couples }\end{array}$} & \multicolumn{3}{|c|}{$\begin{array}{c}\text { Model } 2 \\
\text { Egalitarian Couples }\end{array}$} & \multicolumn{3}{|c|}{$\begin{array}{c}\text { Model } 3 \\
\text { Traditional Couples }\end{array}$} & \multicolumn{3}{|c|}{$\begin{array}{c}\text { Model } 4 \\
\text { Egalitarian Couples }\end{array}$} \\
\hline & Coeff. & $\mathrm{SE}$ & $\begin{array}{l}\text { Odds } \\
\text { ratio }\end{array}$ & Coeff. & SE & $\begin{array}{l}\text { Odds } \\
\text { ratio }\end{array}$ & Coeff. & SE & $\begin{array}{l}\text { Odds } \\
\text { ratio }\end{array}$ & Coeff. & $\mathrm{SE}$ & $\begin{array}{c}\text { Odds } \\
\text { ratio }\end{array}$ \\
\hline Home ownership & -1.42 & 0.33 & $0.24 * *$ & -1.52 & 0.43 & $0.21 * *$ & -1.35 & 0.33 & $0.26^{* *}$ & -1.54 & 0.43 & $0.21 * *$ \\
\hline Length of residence & -0.04 & 0.03 & 0.96 & -0.04 & 0.02 & $0.96^{*}$ & -0.06 & 0.03 & $0.95 * *$ & -0.05 & 0.02 & $0.95 * *$ \\
\hline Average age & -0.03 & 0.02 & $0.97 *$ & 0.02 & 0.02 & 1.02 & -0.04 & 0.02 & $0.96 * *$ & 0.02 & 0.02 & 1.02 \\
\hline Married & 0.10 & 0.30 & 1.10 & -0.32 & 0.33 & 0.73 & 0.13 & 0.30 & 1.13 & -0.31 & 0.33 & $0.74 *$ \\
\hline Household size & -0.12 & 0.12 & $0.89 *$ & 0.02 & 0.18 & 1.02 & -0.11 & 0.12 & 0.89 & 0.01 & 0.17 & 1.01 \\
\hline Urban area & 0.01 & 0.23 & 1.01 & 0.17 & 0.25 & 1.18 & 0.06 & 0.23 & 1.06 & 0.26 & 0.25 & 1.30 \\
\hline \multicolumn{13}{|l|}{ Education } \\
\hline Male years & 0.28 & 0.05 & $1.31 * *$ & 0.09 & 0.06 & 1.09 & & & & & & \\
\hline Female years & -0.04 & 0.06 & 0.96 & 0.15 & 0.06 & $1.17 * *$ & & & & & & \\
\hline Low male/high female $(\alpha)$ & & & & & & & -0.07 & 0.49 & 0.92 & 1.33 & 0.39 & $3.78 * *$ \\
\hline High male/low female $(\beta)$ & & & & & & & 1.42 & 0.31 & $4.16^{* *}$ & 1.03 & 0.39 & $2.81 * *$ \\
\hline High male/high female $(\gamma)$ & & & & & & & 1.29 & 0.28 & $3.62 * *$ & 1.39 & 0.32 & $4.03 * *$ \\
\hline \multicolumn{13}{|l|}{ Senority } \\
\hline Male years & -0.02 & 0.02 & 0.98 & -0.01 & 0.02 & 0.99 & & & & & & \\
\hline Female years & -0.07 & 0.03 & $0.93 * *$ & -0.12 & 0.04 & $0.89 * *$ & & & & & & \\
\hline Low male/high female $(\alpha)$ & & & & & & & 0.07 & 0.29 & 1.07 & -0.16 & 0.29 & 0.85 \\
\hline High male/low female $(\beta)$ & & & & & & & -0.29 & 0.36 & 0.75 & -0.73 & 0.43 & $0.48 *$ \\
\hline High male/high female $(\gamma)$ & & & & & & & -0.68 & 0.36 & $0.51^{*}$ & -1.37 & 0.53 & $0.25 * *$ \\
\hline Year & 0.02 & 0.02 & & 0.04 & 0.02 & & 0.02 & 0.02 & 1.02 & 0.05 & 0.02 & $1.05 * *$ \\
\hline Constant & -5.73 & 0.80 & & -7.48 & 0.86 & & -3.36 & 0.56 & & -5.57 & 0.75 & \\
\hline Number of observations & \multicolumn{3}{|c|}{19,037} & \multicolumn{3}{|c|}{10,420} & \multicolumn{3}{|c|}{19,037} & \multicolumn{3}{|c|}{10,420} \\
\hline Number of households & \multicolumn{3}{|c|}{4,478} & \multicolumn{3}{|c|}{3,752} & \multicolumn{3}{|c|}{4,478} & \multicolumn{3}{|c|}{3,752} \\
\hline Log-likelihood & \multirow{2}{*}{\multicolumn{3}{|c|}{$\begin{array}{l}-535.06 \\
116.20^{* *}\end{array}$}} & \multirow{2}{*}{\multicolumn{3}{|c|}{$\begin{array}{r}-430.37 \\
86.73 * *\end{array}$}} & \multirow{2}{*}{\multicolumn{3}{|c|}{$\begin{array}{l}-548.50 \\
101.78^{* *}\end{array}$}} & \multirow{2}{*}{\multicolumn{3}{|c|}{$\begin{array}{l}-436.13 \\
67.48 * *\end{array}$}} \\
\hline Model $\chi^{2}$ & & & & & & & & & & & & \\
\hline
\end{tabular}

Note: standard errors corrected for multiple observations on household level, high education $=12$ or more education years; high seniority $=5$ or more years with the same employer; $* p<.10 ; * * p<.05$ 
Table 7. Joint coding of male and female characteristics

\begin{tabular}{lcc}
\hline & \multicolumn{2}{c}{ Female education / seniority } \\
\cline { 2 - 3 } Male education / seniority & Low & High \\
\hline Low & Baseline & $\alpha$ \\
High & $\beta$ & $\gamma$ \\
\hline
\end{tabular}


Table 8. Average combined commute-to-work distances (in $\mathrm{km}$ ) of dual-earner couples, by education levels and gender role ideology

\begin{tabular}{lcc}
\hline Education levels & Traditional & Egalitarian \\
\hline Low male/low female & 37.51 & 41.23 \\
Low male/high female & 42.58 & 52.21 \\
High male/low female & 44.01 & 51.11 \\
High male/high female & 54.96 & 60.33 \\
\hline
\end{tabular}

Source: SOEP 1985-2003; author's calculations 
Appendix:

Table A1. Sample Description

\begin{tabular}{|c|c|c|c|c|c|c|c|c|c|c|}
\hline Variable & \multicolumn{2}{|c|}{$\begin{array}{c}\text { single man } \\
\text { in labor force }\end{array}$} & \multicolumn{2}{|c|}{$\begin{array}{c}\text { single woman in labor } \\
\text { force }\end{array}$} & \multicolumn{2}{|c|}{$\begin{array}{l}\text { couple, man in labor } \\
\text { force }\end{array}$} & \multicolumn{2}{|c|}{$\begin{array}{c}\text { couple, woman in labor } \\
\text { force }\end{array}$} & \multicolumn{2}{|c|}{$\begin{array}{l}\text { couple, both } \\
\text { in labor force }\end{array}$} \\
\hline Male age & 39.39 & 11.73 & & & 45.45 & 11.37 & 58.85 & 9.71 & 42.00 & 10.51 \\
\hline Male education & 12.05 & 2.84 & & & 11.34 & 2.71 & 10.84 & 2.41 & 11.70 & 2.70 \\
\hline Female age & & & 40.06 & 12.82 & 43.01 & 11.93 & 53.39 & 8.86 & 39.12 & 10.14 \\
\hline Female education & & & 11.81 & 2.73 & 10.34 & 2.20 & 10.50 & 2.34 & 11.27 & 2.47 \\
\hline Household Size & 1.41 & 0.87 & 1.77 & 1.00 & 3.71 & 1.37 & 2.69 & 1.05 & 3.22 & 1.13 \\
\hline Urban area & 0.45 & 0.50 & 0.44 & 0.50 & 0.30 & 0.46 & 0.38 & 0.48 & 0.31 & 0.46 \\
\hline Home ownership & 0.21 & 0.40 & 0.22 & 0.41 & 0.47 & 0.50 & 0.46 & 0.50 & 0.44 & 0.50 \\
\hline Length of residence (years) & 8.03 & 10.42 & 9.28 & 11.37 & 12.99 & 11.80 & 18.87 & 14.83 & 10.37 & 10.70 \\
\hline $\mathrm{N}$ & \multicolumn{2}{|c|}{9,122} & \multicolumn{2}{|c|}{10,920} & \multicolumn{2}{|c|}{15,015} & \multicolumn{2}{|c|}{2,370} & \multicolumn{2}{|c|}{33,045} \\
\hline
\end{tabular}

Note: Numbers observation may vary due to missing values 
Table A2. Logistic regressions predicting the geographical mobility of dual-earner couples, alternative specifications of the egalitarian

\begin{tabular}{|c|c|c|c|c|c|c|c|c|c|c|c|c|}
\hline \multirow[b]{3}{*}{ Covariate } & \multicolumn{6}{|c|}{ Threshold $=.25$} & \multicolumn{6}{|c|}{ Threshold $=.50$} \\
\hline & \multicolumn{3}{|c|}{ Model 1 (Traditional) } & \multicolumn{3}{|c|}{ Model 2 (Egalitarian) } & \multicolumn{3}{|c|}{ Model 3 (Traditional) } & \multicolumn{3}{|c|}{ Model 4 (Egalitarian) } \\
\hline & Coeff. & SE & $\begin{array}{c}\text { Odds } \\
\text { ratio }\end{array}$ & Coeff. & SE & $\begin{array}{c}\text { Odds } \\
\text { ratio }\end{array}$ & Coeff. & SE & $\begin{array}{c}\text { Odds } \\
\text { ratio }\end{array}$ & Coeff. & SE & $\begin{array}{l}\text { Odds } \\
\text { ratio }\end{array}$ \\
\hline Home ownership & -1.48 & 0.57 & $0.22 * *$ & -1.38 & 0.43 & $0.25^{* *}$ & -1.60 & 0.37 & $0.20^{* *}$ & -0.73 & 0.81 & 0.48 \\
\hline Length of residence & -0.04 & 0.04 & 0.96 & -0.05 & 0.02 & $0.95 * *$ & -0.04 & 0.02 & $0.96^{* *}$ & -0.08 & 0.02 & 0.93 \\
\hline Average age & -0.03 & 0.02 & $0.97 *$ & -0.00 & 0.02 & 0.997 & -0.03 & 0.02 & $0.97 * *$ & 0.04 & 0.04 & 1.04 \\
\hline Married & -0.11 & 0.42 & 0.89 & -0.21 & 0.43 & 0.81 & -0.03 & 0.33 & 0.97 & -0.56 & 0.63 & 0.57 \\
\hline Household size & -0.21 & 0.18 & $0.81^{*}$ & 0.02 & 0.19 & 1.02 & -0.07 & 0.15 & $0.93^{* *}$ & 0.04 & 0.27 & 1.04 \\
\hline Urban area & -0.15 & 0.35 & 0.86 & 0.20 & 0.30 & 1.22 & 0.07 & 0.26 & 1.07 & 0.18 & 0.50 & 1.20 \\
\hline \multicolumn{13}{|l|}{ Education } \\
\hline Low male/high female $(\alpha)$ & 0.11 & 1.01 & 1.12 & 1.13 & 0.52 & $3.08^{* *}$ & 0.51 & 0.72 & $1.66^{*}$ & 1.62 & 0.70 & $5.06^{* *}$ \\
\hline High male/low female $(\beta)$ & 1.29 & 0.43 & $3.62 * *$ & 1.16 & 0.42 & $3.18^{* *}$ & 1.21 & 0.34 & $3.36^{* *}$ & 1.05 & 0.78 & $2.86^{*}$ \\
\hline High male/high female $(\gamma$ & 1.06 & 0.44 & $2.88^{* *}$ & 1.57 & 0.38 & $4.81^{* *}$ & 1.30 & 0.33 & $3.68 * *$ & 1.81 & 0.69 & $6.11 * *$ \\
\hline \multicolumn{13}{|l|}{ Seniority } \\
\hline Low male/high female $(\alpha)$ & -0.08 & 0.44 & 0.92 & 0.04 & 0.37 & 1.04 & 0.07 & 0.33 & 1.08 & -0.28 & 0.64 & 0.76 \\
\hline High male/low female $(\beta)$ & -0.61 & 0.55 & 0.54 & -0.08 & 0.40 & 0.92 & -0.24 & 0.35 & 0.79 & -0.14 & 1.04 & 0.87 \\
\hline High male/high female $(\gamma)$ & -0.30 & 0.48 & 0.74 & -1.37 & 0.48 & $0.40^{*}$ & -0.69 & 0.38 & $0.50 * *$ & -1.48 & 0.83 & $0.23 * *$ \\
\hline Year & 0.02 & 0.04 & 1.02 & 0.03 & 0.04 & $0.25^{* *}$ & 0.05 & 0.03 & $1.05^{* *}$ & -0.05 & 0.05 & 0.95 \\
\hline Constant & -2.92 & 0.78 & & -4.79 & 0.67 & & -3.76 & 0.58 & & -5.41 & 1.13 & \\
\hline $\mathrm{N}$ observations & \multicolumn{3}{|c|}{15,245} & \multicolumn{3}{|c|}{16,478} & \multicolumn{3}{|c|}{28,110} & \multicolumn{3}{|c|}{3,613} \\
\hline $\mathrm{N}$ households & \multicolumn{3}{|c|}{4,042} & \multicolumn{3}{|c|}{4,760} & \multicolumn{3}{|c|}{5,588} & \multicolumn{3}{|c|}{1,946} \\
\hline Log-likelihood & \multirow{2}{*}{\multicolumn{3}{|c|}{$\begin{array}{l}-412.72 \\
80.59^{* *}\end{array}$}} & \multirow{2}{*}{\multicolumn{3}{|c|}{$\begin{array}{l}-699.45 \\
113.22^{* *}\end{array}$}} & \multirow{2}{*}{\multicolumn{3}{|c|}{$\begin{array}{l}-905.99 \\
141.09^{* *}\end{array}$}} & \multirow{2}{*}{\multicolumn{3}{|c|}{$\begin{array}{c}-203.35 \\
63.17^{* *}\end{array}$}} \\
\hline Model $\chi^{2}$ & & & & & & & & & & & & \\
\hline
\end{tabular}

Note: standard errors corrected for multiple observations on household level, high education $=12$ or more education years; high seniority $=5$ or more years with the same employer; ${ }^{*} p<.10 ;{ }^{* *} p<.05$ 


\section{Discussion Paper Series}

Mannheim Research Institute for the Economics of Aging Universität Mannheim

To order copies, please direct your request to the author of the title in question.

\begin{tabular}{|c|c|c|c|}
\hline Nr. & Autoren & Titel & Jahr \\
\hline $76-05$ & $\begin{array}{l}\text { Karsten Hank } \\
\text { Hendrik Jürges }\end{array}$ & $\begin{array}{l}\text { Gender and the Division of Household Labor in } \\
\text { Older Couples: A European Perspective }\end{array}$ & 05 \\
\hline 78-05 & $\begin{array}{l}\text { Daniel Schunk } \\
\text { Cornelia Betsch }\end{array}$ & $\begin{array}{l}\text { Explaining heterogeneity in utility functions by } \\
\text { individual differences in decision modes }\end{array}$ & 05 \\
\hline 79-05 & $\begin{array}{l}\text { Franz Rothlauf } \\
\text { Daniel Schunk } \\
\text { Jella Pfeiffer }\end{array}$ & $\begin{array}{l}\text { Classification of Human Decision Behavior: } \\
\text { Finding Modular Decision Rules with Genetic } \\
\text { Algorithms }\end{array}$ & O5 \\
\hline $80-05$ & Lothar Essig & Methodological aspects of the SAVE data set & 05 \\
\hline $81-05$ & Lothar Essig & $\begin{array}{l}\text { Imputing total expenditures from a non-exhaustive } \\
\text { list of items: An empirical assessment using the } \\
\text { SAVE data set }\end{array}$ & 05 \\
\hline $82-05$ & Mathias Sommer & $\begin{array}{l}\text { Trends in German households' portfolio behavior } \\
\text { - assessing the importance of age- and cohort- } \\
\text { effects }\end{array}$ & 05 \\
\hline $83-05$ & Lothar Essig & $\begin{array}{l}\text { Household Saving in Germany: Results from } \\
\text { SAVE 2001-2003 }\end{array}$ & 05 \\
\hline 84-05 & Lothar Essig & $\begin{array}{l}\text { Precautionary saving and old-age provisions: Do } \\
\text { subjective saving motive measures work? }\end{array}$ & 05 \\
\hline $85-05$ & $\begin{array}{l}\text { Axel Börsch-Supan } \\
\text { Lothar Essig }\end{array}$ & $\begin{array}{l}\text { Personal assets and pension reform: How well } \\
\text { prepared are the Germans? }\end{array}$ & 05 \\
\hline $86-05$ & Lothar Essig & $\begin{array}{l}\text { Measures for savings and saving rates in the } \\
\text { German SAVE data set }\end{array}$ & 05 \\
\hline $87-05$ & $\begin{array}{l}\text { Felix Freyland ed. by } \\
\text { Axel Börsch-Supan }\end{array}$ & $\begin{array}{l}\text { Household Composition and Savings: An } \\
\text { Overview }\end{array}$ & 05 \\
\hline $88-05$ & $\begin{array}{l}\text { Felix Freyland ed. by } \\
\text { Axel Börsch-Supan }\end{array}$ & $\begin{array}{l}\text { Household Composition and Savings: An } \\
\text { Empirical Analysis based on the German SOEP } \\
\text { Data }\end{array}$ & 05 \\
\hline $89-05$ & Hendrik Jürges & $\begin{array}{l}\text { Unemployment, restrospective error, and life } \\
\text { satisfaction }\end{array}$ & 05 \\
\hline $90-05$ & Hendrik Jürges & $\begin{array}{l}\text { Gender Ideology, Division of Housework, and the } \\
\text { Geographic Mobility Families }\end{array}$ & 05 \\
\hline
\end{tabular}

